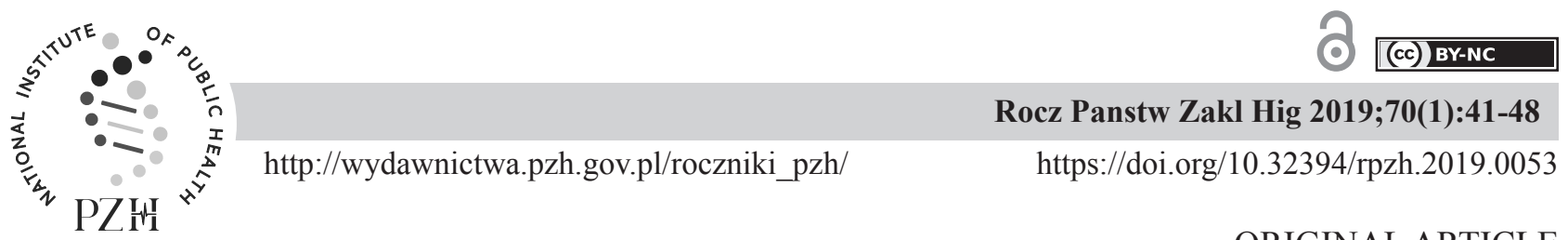

ORIGINAL ARTICLE

\title{
NUTRITION KNOWLEDGE OF PEOPLE WITH EATING DISORDERS
}

\author{
Beata Całyniuk', Michat Górski², Jagoda Garbicz², Elizbieta Grochowska-Niedworok ${ }^{1}$ \\ ${ }^{1}$ Department of Human Nutrition, Faculty of Public Health in Bytom, \\ Medical University of Silesia in Katowice, Poland \\ ${ }^{2}$ Student Scientific Team at the Department of Human Nutrition, Faculty of Public Health in Bytom, \\ Medical University of Silesia in Katowice, Poland
}

\begin{abstract}
Background: Eating disorders are an increasingly common health problem that is a major therapeutic challenge. For many years, the basic form of therapy used to be psychiatric and psychotherapeutic treatment, but now it is postulated that the dietetician should also be part of the therapeutic teams.

Objective: The main purpose of the study is to assess nutrition knowledge of people with eating disorders with consideration to their age, place of living, education, BMI, type of disease, participation in dietary consultations and in therapy.

Material and methods: Nutrition knowledge of the respondents was assessed by means of an author's survey questionnaire. The questionnaire was published in one of the social portals in the "Eating disorders - tackling" group gathering people with different types of eating disorders. The survey questionnaire consisted in 33 questions. Arithmetic mean and standard deviation for the number of correct answers provided by the respondents by the selected criteria.

Results: In terms of age, the least nutrition knowledge was attributable to the persons below 20 years of age (25.24 points in average). When considering the place of living, the least nutrition knowledge was revealed among the subjects living in medium cities (between 20 and 100 thousand of population) i.e. 25.31 points. In terms of education, the least nutrition knowledge was recorded in people with vocational education (24.83 points). When classifying the respondents by BMI, the highest average score was gained by the respondents with normal body mass index (BMI) (26.42 points).

Conclusions: The study on the level of nutrition knowledge among the people with eating disorders demonstrated that this knowledge was selective and insufficient to provide rational nutrition. It aimed at teaching the rules of healthy lifestyle and nutrition and thorough discussing of all nutrients, their functions and effect on the body.
\end{abstract}

Key words: nutrition knowledge, eating disorders, nutrition, lifestyle

\section{STRESZCZENIE}

Wprowadzenie. Zaburzenia odżywiania są coraz powszechniejszym problemem zdrowotnym stanowiącym duże wyzwanie terapeutyczne. Przez wiele lat podstawową formą terapii było leczenie psychiatryczne i psychoterapeutyczne, obecnie postuluje się, aby w skład zespołów terapeutycznych wchodził również dietetyk.

Cel badań. Głównym celem badania jest ocena wiedzy żywieniowej osób z zaburzeniami odżywiania się z uwzględnieniem ich wieku, miejsca zamieszkania, wykształcenia, BMI, rodzaju choroby, udziału w konsultacjach dietetycznych i terapii.

Materiał i metody. Wiedzę żywieniową respondentów oceniano za pomocą autorskiego kwestionariusza ankiety. Kwestionariusz został opublikowany w jednym z portali społecznościowych „Zaburzenia odżywiania - walka”, gromadzącej osoby z różnymi rodzajami zaburzeń. Kwestionariusz ankiety składał się z 33 pytań. Obliczono średnią arytmetyczną i odchylenie standardowe dla liczby poprawnych odpowiedzi udzielonych przez respondentów według przyjętych kryteriów. Wyniki. Pod względem wieku najmniejszą wiedzą żywieniową można przypisać osobom poniżej 20 roku życia (średnio 25,24 pkt). Biorąc pod uwagę miejsce zamieszkania, najmniejszą wiedzę żywieniową stwierdzono ród osób zamieszkujących średnie miasta (od 20 do 100 tysięcy ludności), tj. 25,31 punktów. Pod względem wykształcenia najmniejszą wiedzę żywieniową odnotowano u osób z wykształceniem zawodowym (24,83 pkt). Przy klasyfikacji respondentów według BMI najwyższy średni wynik uzyskali respondenci z prawidłowym wskaźnikiem masy ciała (BMI) (26,42 pkt).

Wnioski. Badanie dotyczące poziomu wiedzy żywieniowej wśród osób z zaburzeniami odżywiania wykazało, że wiedza ta była selektywna i niewystarczająca do zapewnienia racjonalnego żywienia. Istnieje konieczność tworzenia zespołów terapeutycznych, w których powinien znajdować się dietetyk. Jego zadaniem powinno być nauczenie zasad zdrowego stylu życia i odżywiania oraz dokładne omówienie wszystkich składników odżywczych, ich funkcji i wpływu na organizm.

Słowa kluczowe: wiedza żywieniowa, zaburzenia odżywiania, odżywianie, styl życia

*Corresponding author: Beata Całyniuk, Śląski Uniwersytet Medyczny w Katowicach, Wydział Zdrowia Publicznego w Bytomiu, Katedra Dietetyki, Zakład Żywienia Człowieka, ul. Jordana 19, 41-808 Zabrze, tel: +48 32275 51 95, e-mail: bcalyniuk@sum.edu.pl

(C) Copyright by the National Institute of Public Health - National Institute of Hygiene 


\section{INTRODUCTION}

Eating disorders pose a great challenge to the contemporary medicine. According to data provided by the National Eating Disorder Association, nearly 70 million of people throughout the world suffer from different eating disorders [18]. This group of diseases is the cause of the greatest number of deaths from among all mental diseases and therefore developing the effective treatment methods is crucial [14]. Eating disorders should not be perceived as a reflection of the prevailing pursuit of weight loss. The underlying cause of these diseases is multifaceted and complex. The fact that people living in the era of wealth and prosperity choose a path of "hunger at the times of repletion" is extremely difficult to explain [5], so as the reason behind attributing the emotions to eating. Equating this essential physiological need of the body with consolation, a sign of bonds, love or entertainment deprives the food of its physiological functions and makes it a way to satisfy the higher needs [21]. Numerous scientific publications bring up the need of taking up studies on nutrition knowledge of people with eating disorders. This need stems from the reports clearly demonstrating that psychotherapy combined with diet therapy has better therapeutic indices than psychotherapy alone [8]. The studies by Waisberg and Woods [23] demonstrated that education in the area of nutrition significantly increased the nutrition knowledge, which was reflected in changed attitudes and behaviours of the subjects. According to the body of literature, the level of nutrition knowledge and health views determine the health behaviours [5]. Thus, studying the behaviours and knowledge is a must for understanding the activities underlying the change of nutrition habits and practices [5].

Patient education in the scope of nutrition knowledge plays a significant role in the recovery process. The key position of dietician in treatment of eating disorders has been emphasized in numerous studies $[7,8,9,13,21]$. The essential aim of nutrition education is to teach the patient how to compose the meals well and to extend knowledge on the rules of proper nutrition. In addition, while on diet therapy, the subject needs to understand that the food satisfies the physiological rather than mental needs.

The main purpose of the study is to assess nutrition knowledge of people with eating disorders with consideration to their age, place of living, education, BMI, type of disease, participation in dietary consultations and in therapy.

\section{MATERIAL AND METHODS}

100 respondents ( 94 women and 6 men) with eating disorders, regardless of their type, were enrolled in the study. The exclusion criteria were targeted on healthy individuals or individuals with diseases failing to meet the eating disorder criterion. The study involved people whose eating disorders were diagnosed by a general practitioner, psychiatrist or other specialist. During the study, no medical certificate was required and the respondents were informed that only people diagnosed by a specialist could take part in it. The study included patients with an active form of the disease.

Participation in the study was voluntary. The respondents were informed about the purpose of the study and its process. The respondents were assured that the surveys were anonymous and the results of the study would be used only for scientific purposes.

The study was conducted electronically. The questionnaire was published in one of the social portals in the "Eating disorders - tackling" group gathering people with different types of eating disorders and aiming at mutual support and encouraging treatment.

$51 \%$ of the respondents were below 20 years of age. The second largest group included the respondents aged 20-25, whereas the smallest groups were the respondents aged 26-30 and above 30 years of age.

$30 \%$ of the respondents lived in large cities with population of 100 thousand and above. Similar number of the respondents (29\%) lived in medium cities (between 20 and 100 thousand of population). A significant number of the respondents inhabited the rural areas, whereas the smallest group originated from small cities of population below 20 thousand.

Substantially all the respondents were the persons with anorexia (55\%) and bulimia (31\%) and only few percent's with night eating syndrome. The other eating disorders $(7 \%)$ included: bigorexia, lack of the sensation of satiety after eating (acoria), lack of appetite and selective eating disorders.

Vast majority of the respondents had upper secondary or higher education. Nutrition knowledge of the respondents was assessed by means of an author's survey questionnaire. The questionnaire contained 20 questions related to nutritional knowledge and 13 questions about metric data. 7 test questions were of multiple choice ones. The respondents were asked about current body mass and height in order to calculate the body mass index (BMI) $\left[\mathrm{kg} / \mathrm{m}^{2}\right]$, interpreted according to the updated standards [10]. The survey developed for the purposes of this study included the questions about the essential nutrients: proteins, fats, carbohydrates (including dietary fiber) and vitamins as well as about caloric value of these components, their functions, sources and percentage share of these components in a balanced diet. The other questions referred to the proper number of meals a day, caloric intake, BMI value and an example of a well composed dinner.

The responses provided by the respondents were assessed by their correctness. The maximum score 
was 36. 20 questions referring to nutrition knowledge were assessed. 1 point was scored for a correct answer in a single choice question and 4 points for a correct answer in a multiple choice question (scores were given for checking of a specific number of correct answers and for non-checking of the incorrect ones). The number of points scored by the respondents was interpreted according to the following scale: 0-21 points - insufficient knowledge, 22-27 points sufficient knowledge, 28-33 points - good knowledge, 34-36 points - excellent knowledge.

Knowledge of the respondents was analysed in terms of: age, place of living, education, BMI, type of disease, participation in dietary consultations and in therapy.

The gamma coefficient was calculated to demonstrate correlations between the actual knowledge of the respondents (assessed on the basis of the provided answers) and self-assessment of the respondents. The adopted significance level was $\leq$ 0.05 . Analysis of correlations between the features referred to above was performed with the use of scale according to Table 1 .

\section{RESULTS}

Considerable majority of the respondents (68\%) used no assistance of the psychotherapy specialist. Only $32 \%$ of them decided to participate in such form of treatment. Also the substantial majority (as many as $72 \%$ ) used no assistance of the human nutrition specialist (Figure 1).

Table 1. The strength of dependence resulting from the dependence ratio

\begin{tabular}{|c|c|}
\hline $\begin{array}{c}\text { The value of the } \\
\text { dependency coefficient }\end{array}$ & The strength of dependence \\
\hline 0 & No dependency \\
\hline$(0 ; 0.2>$ & Weak \\
\hline$(0.2 ; 0.4>$ & Low \\
\hline$(0.4 ; 0.7>$ & Moderate \\
\hline$(0.7 ; 0.9>$ & High \\
\hline$(0.9 ; 1.0)$ & Very high \\
\hline 1 & Functional dependence \\
\hline
\end{tabular}

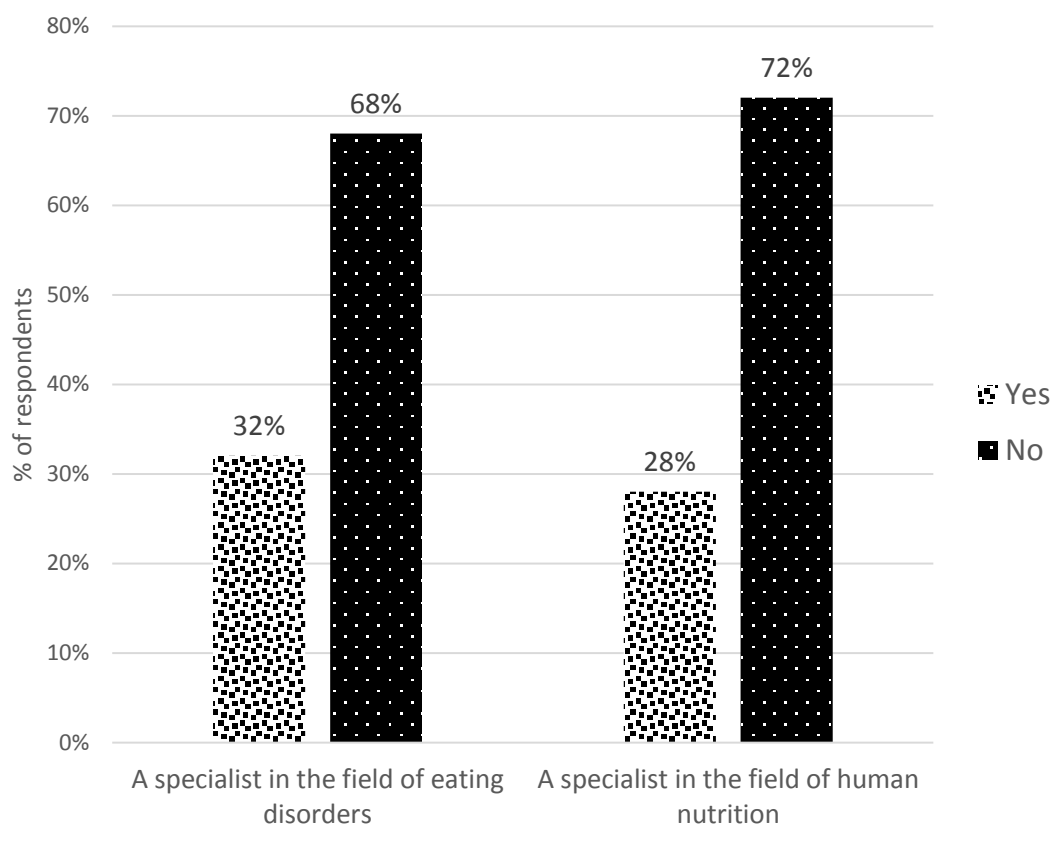

Figure 1. Participation of the respondents in psychotherapy and dietary consultations

Substantially all respondents displayed nutrition knowledge at sufficient level, while only 5 of them had excellent knowledge on human nutrition. Almost $1 / 5$ of the respondents demonstrated insufficient knowledge (Figure 2).

The respondents were asked to rate their nutritional knowledge on a scale of 1 to 5 , where 1 meant the lowest (insufficient) and 5 - the highest (very good) grade. Considerable majority of the respondents assessed their nutrition knowledge as good and sufficient and only 1 respondent considered its level as insufficient (Figure 3).
Arithmetic mean and standard deviation for the number of correct answers provided by the respondents by the selected criteria, including: age, place of living, education, BMI, type of disease, participation in dietary consultations and in therapy, was calculated. In terms of age, the least nutrition knowledge was attributable to the persons below 20 years of age (25.24 points in average) (Table 2 ). When considering the place of living, the least nutrition knowledge was revealed among the subjects living in medium cities (between 20 and 100 thousand of population) i.e. 
25.31 points. The respondents inhabiting rural areas gained the highest average score in the questionnaire (26.32 points). In terms of education, the least nutrition knowledge was recorded in people with vocational education (24.83 points). When classifying the respondents by BMI, the highest average score was gained by the respondents with normal body mass index (BMI) (26.42 points). While adopting the type of disease as a differentiating criterion, the individuals with compulsive eating obtained the lowest average score (24.26 points). The respondents not consulted by a human nutrition specialist as well as these not participating in therapy had lower nutrition knowledge comparing to the respondents that took part in dietary consultations and therapy. The above results were not statistically significant.

On the basis of the performed Gamma correlation coefficient test, correlation between actual knowledge (knowledge assessment) and self-assessment of the respondents, people with eating disorders, for $\alpha=$ $0.05, p=0.007$, was determined.

Calculated value of the Gamma correlation coefficient amounts to 0.27 , which means, that the magnitude of correlation between the actual knowledge (knowledge assessment) and self-assessment of the respondents in the studied group is low (Figure 4).

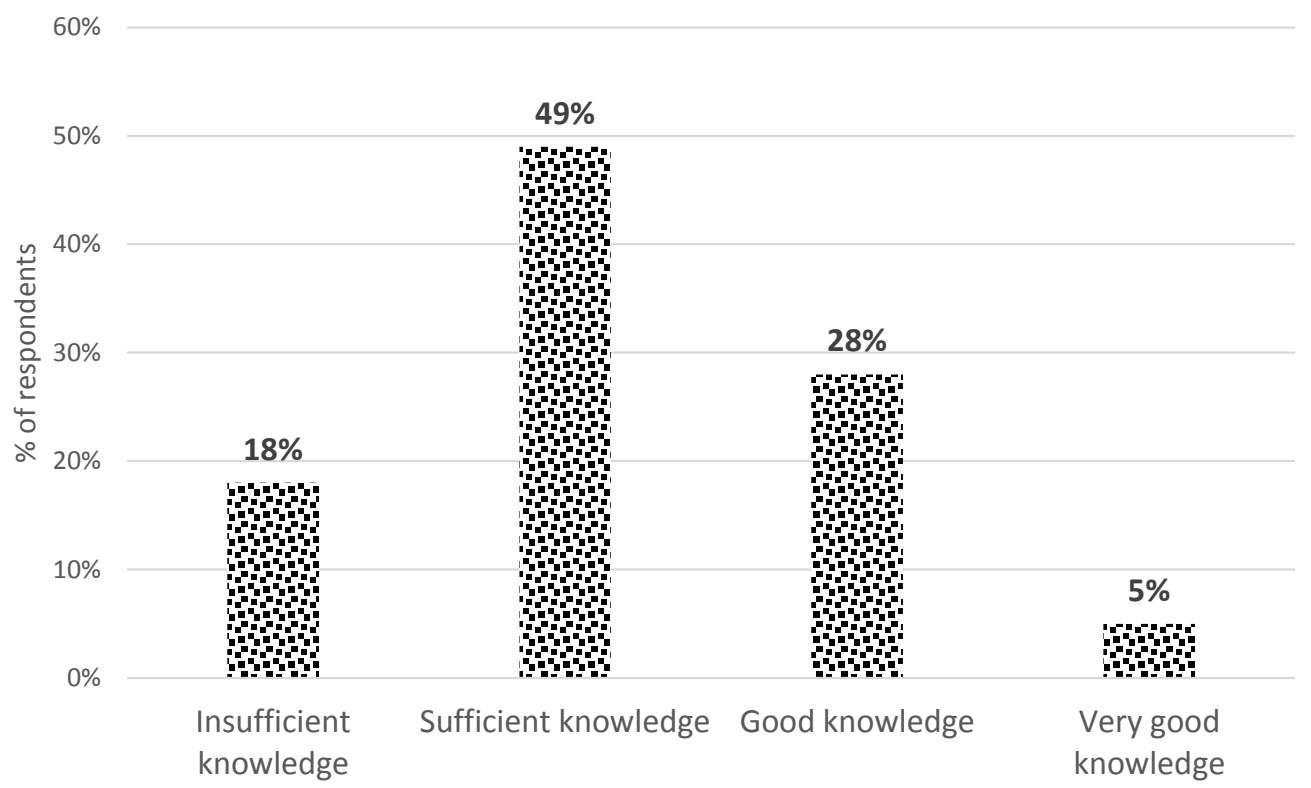

Figure 2. Assessment of nutritional knowledge of the respondents

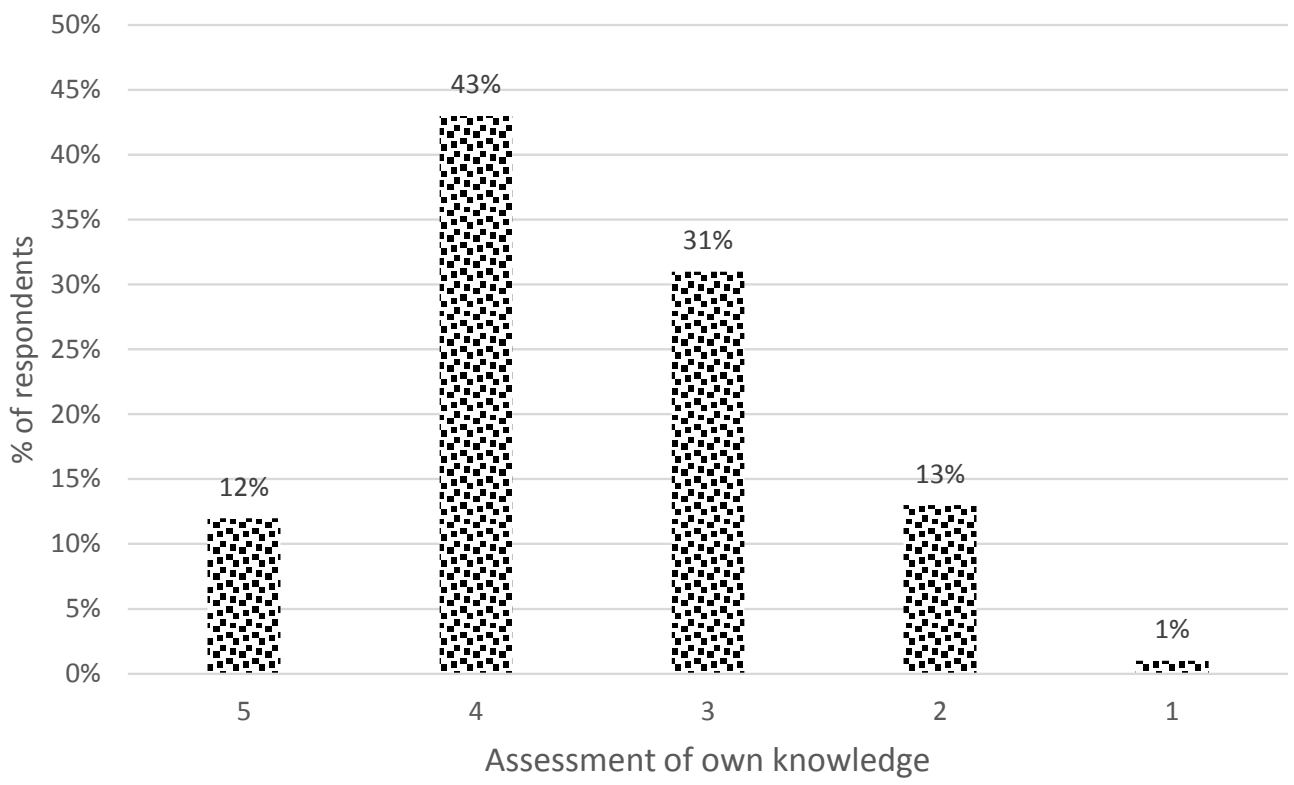

Figure 3. Opinion of the respondents on their own knowledge in the field of human nutrition

Since $>0$ and as the result of the Gamma correlation coefficient test is statistically significant, the values of analysed random variables for a certain part of subjects in the sample and in the studied general population are ordered in the same direction. 


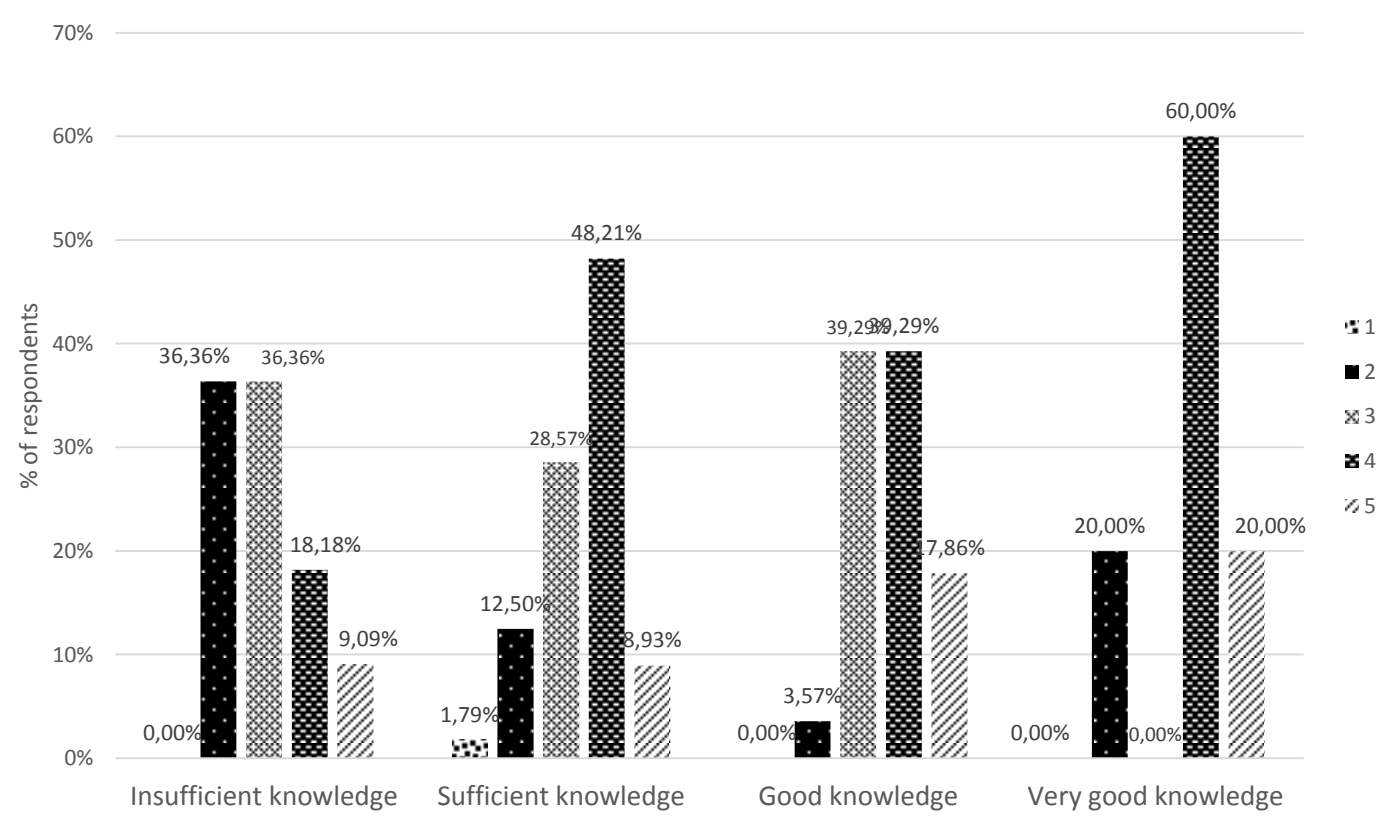

Figure 4. Knowledge assessment obtained on the basis of the questionnaire and self-assessment of the respondents

Table 2. Analysis of the average number of points obtained from the survey depending on the selected criterion

\begin{tabular}{|c|c|c|}
\hline Criterion & Classification (n) & $\begin{array}{l}\text { Arithmetic mean of the number of points } \\
\text { obtained }( \pm \text { SD) }\end{array}$ \\
\hline \multirow{4}{*}{ Age [years] } & $<20(51)$ & $25.24( \pm 3.81)$ \\
\hline & $20-25(37)$ & $26.43( \pm 4.67)$ \\
\hline & $26-30(6)$ & $26.67( \pm 6.31)$ \\
\hline & $>30(6)$ & $25.33( \pm 4.76)$ \\
\hline \multirow{4}{*}{ Place of residence } & Village (25) & $26.32( \pm 4.64)$ \\
\hline & Small city (16) & $26.00( \pm 3.85)$ \\
\hline & Medium city (29) & $25.31( \pm 4.21)$ \\
\hline & Big city (30) & $25.63( \pm 4.58)$ \\
\hline \multirow{4}{*}{ Education } & Basic (24) & $25.00( \pm 4.04)$ \\
\hline & Vocational (12) & $24.83( \pm 2.76)$ \\
\hline & Secondary (46) & $26.24( \pm 4.58)$ \\
\hline & Higher (18) & $26.22( \pm 4.95)$ \\
\hline \multirow{3}{*}{ BMI } & Underweight (57) & $25.56( \pm 4.00)$ \\
\hline & Normal weight (38) & $26.42( \pm 4.91)$ \\
\hline & Overweight or obesity (5) & $23.20( \pm 2.17)$ \\
\hline \multirow{6}{*}{ Type of disease } & Anorexia nervosa (55) & $25.78( \pm 4.19)$ \\
\hline & Bulimia nervosa (31) & $25.90( \pm 3.81)$ \\
\hline & Orthorexia nervosa (14) & $28.10( \pm 3.53)$ \\
\hline & Compulsive overeating (25) & $24.26( \pm 3.19)$ \\
\hline & Night eating (10) & $25.30( \pm 3.19)$ \\
\hline & Other (7) & $24.33( \pm 5.85)$ \\
\hline \multirow{2}{*}{ Consultation with a dietitian } & Yes (28) & $27.62( \pm 4.72)$ \\
\hline & No (72) & $25.04( \pm 3.98)$ \\
\hline \multirow{2}{*}{ Participation in therapy } & Yes (32) & $27.84( \pm 4.82)$ \\
\hline & No $(68)$ & $24.79( \pm 3.74)$ \\
\hline
\end{tabular}




\section{DISCUSSION}

Many scientists emphasize the important role played by a multi-disciplinary team in the recovery process. This includes primarily the role of dieticians focused for the most on nutrition education, correcting improper nutrition behaviours and control over the nutrition treatment $[2,8]$. Nevertheless, the fact that such form of assistance was used by only $32 \%$ of the respondents might be disturbing. This imposes the need for improving the treatment conditions in this area and for establishment of the specialist centers offering simultaneous therapy provided by a multidisciplinary team. Analysis of the results of studies performed on the subjects with bulimia demonstrated that nutrition education combined with psychotherapy brought a significant reduction of eating attacks or their remission [15]. Hsu et al. [10] compared the effectiveness of cognitive therapy and nutrition therapy as well as combination of these two methods. It was demonstrated that these methods resulted in significant reduction in the number of eating episodes and the use of compensation methods, while simultaneous nutrition and cognitive therapies contributed to better self-control and higher reduction of improper behaviours. Therefore, proper nutrition education and increased nutrition knowledge can influence discontinuation of bulimic behaviours. This thesis was confirmed in the study by O'Connor et al. [19]. Similar studies performed on the subjects with anorexia provide no unambiguous results. Sarfety et al. [22] demonstrated that better nutrition knowledge in the subjects with anorexia does not affect the recovery process, while Waisberg and Woods [23] proved that nutrition education resulted in a significant change of nutrition behaviours in this group of subjects.

While assessing the nutrition knowledge, it was found that this knowledge differed depending on the group. In context of age, the highest average score was obtained by the respondents in the 26-30 age group (26.67 points, \pm 6.31 ). The least nutrition knowledge was recorded in the persons below 20 years of age (25.24 points, \pm 3.81 ).

Analysis of the average score demonstrated that the persons inhabiting rural areas have the most extensive nutrition knowledge (26.32 points, $\pm 4.64)$. These results may surprise since according to numerous scientific studies the persons living in urban areas display greater nutrition awareness comparing to these living in rural areas [4]. Considering the size of the city, it can be noted that the respondents living in a medium or large city have lesser nutrition knowledge comparing to the respondents living in a small city.

In terms of education of the respondents, it can be found that the most extensive nutrition knowledge is recorded among the persons with upper secondary education (26.24 points, \pm 4.58 ), while the subjects with higher education obtained a similar average score (26.22 points, \pm 4.95 ). This study proves also that people with vocational education have the least nutrition knowledge. The study of OstachowskaGasior et al. [20] obtained distinct results. In this study, the best knowledge was recorded in the respondents with higher education. It is surprising that in the quoted study the persons with vocational education have better nutrition knowledge than these with upper secondary education.

In terms of BMI classification, the most extensive nutrition knowledge was demonstrated by the respondents with normal body mass index (26.42 points, \pm 4.91 ), whereas the least knowledge in this area was displayed by overweight or obese people (23.20 points, \pm 2.17 ). Also the underweight persons demonstrated lesser knowledge comparing to these with normal BMI. This may prove the theory that each deviation from normal body mass and presence of eating disorders are correlated with improper nutrition knowledge. However, the Weker et al [24] study, which included children aged 13-15, shows that the level of knowledge about proper nutrition was higher in obese adolescents than in children with right body weight.

While analysing the average score obtained by the respondents in terms of type of their disorder, it can be found that the least nutrition knowledge is specific for the persons with compulsive eating disorder (24.26 point, \pm 3.19 ), whereas the best knowledge is attributable to the persons with orthorexia (28.10 points, \pm 3.53$)$. It can be suspected that these results are closely correlated with the type of disease. Compulsive eating consists in consuming large volumes of food in a short time period, with loss of control over the types of the consumed products and their quantity $[1,3,6]$. During the attack, people with compulsive eating disorder frequently consume the products that are commonly considered unhealthy, of high caloric value and with high content of fat and carbohydrates. There is no division into "good" and "bad" products. People with compulsive eating disorder believe that all that is eatable is food and do not care about the caloric intake and nutrients provided by a given product $[3,6]$, while the subjects with orthorexia impose numerous dietary restrictions on themselves, exclude processed products and chemical additives in a form of chemicals $[12,17]$. Restrictions in consumption of specific types of products are far more extensive than the ones recommended by the specialists, therefore it can be concluded that people with orthorexia have broad knowledge on human nutrition and advanced nutrition knowledge.

This study demonstrated no significant differences between the level of nutrition knowledge of the 
subjects with anorexia and bulimia. The persons with diagnosed anorexia nervosa obtained 25.78 points $( \pm 4.19)$ in average, while these with bulimia nervosa obtained $25.90( \pm 3.81)$ in average in the questionnaire. Similar results were provided also in two other independent studies. One of the first studies in the world that assessed the level of nutrition knowledge in people with eating disorders was performed in Germany in 1988 [16]. It was found that the results assessing the level of nutrition knowledge of the patients with anorexia and bulimia were equivalent. The other study [5], carried out in Poland in 2007, also displayed no differences in the level of nutrition knowledge for these two diseases.

The study showed however certain differences in the level of nutrition knowledge in the respondents who were consulted by a dietician and the persons without such consultation. Average score obtained by the first of the discussed groups was 27.64, whereas the persons without consultation gained only 25.04 points. Therefore, it can be stated that an appointed visit to a human nutrition specialist contributed to better nutrition knowledge which is reflected in the obtained score.

The survey performed for the purposes of this study assessed also the level of nutrition knowledge depending on participation in the therapy. The methods commonly applied in treatment of eating disorders include psychotherapy and pharmacotherapy. Psychotherapy consists in behavioural therapy, interpersonal therapy, family therapy and familiarises with the methods of handling high-stress situations [6]. The most commonly applied therapeutic methods in eating disorders include cognitive and behavioural therapy aiming at identifying the core cause of disease and changing the previous behaviours [3]. According to the obtained results, the knowledge of people participating in these forms of treatment is by 3 points higher comparing to the persons avoiding therapy. These results can confirm the effectiveness of therapies and argue for the need of introducing the clinical dieticians to the group of specialists treating the nutrition disorders.

\section{CONCLUSIONS}

1. The study showed that the lowest level of nutritional knowledge was characteristic of respondents under the age of 20 , living in a small town, with vocational education, and not using a dietician's or therapist's help.

2. The study on the level of nutrition knowledge among the people with eating disorders demonstrated that this knowledge was selective and insufficient to provide rational nutrition. It aimed at teaching the rules of healthy lifestyle and nutrition and thorough discussing of all nutrients, their functions and effect on the body.

3. The persons with eating disorders hardly use the assistance of dietary specialists. The task of such specialists is to offer nutrition education, correct improper nutrition behaviours and control over nutrition therapy.

\section{Conflict of interest}

The authors declare no conflict of interest.

\section{REFERENCES}

1. American Psychiatric Association. Diagnostic and statistical manual of mental disorders (4th ed.). American Psychiatric Association Washington, DC.1994.

2. Bator E., Bronowska M., Ślepecki D., Biernat J.: Anoreksja - przyczyny, przebieg, leczenie [Anorexia causes, course, treatment]. Now Lek 2011; 80(3): 184191 (in Polish).

3. Bąk-Sosnowska M.: Interwencja psychologiczna w zespole kompulsywnego jedzenia [Psychological intervention in binge eating disorder]. Psychiatr Pol 2009; 43(4): 445-456 (in Polish).

4. Chęcińska Z., Krauss H., HajdukM, Białecka-Grabarz $K .:$ Ocena sposobu żywienia młodzieży wielkomiejskiej i obszarów wiejskich [Assessment of eating habits in urban and rural youth]. Probl Hig Epidemiol 2013; 94(4): 780-785 (in Polish).

5. Czarnewicz-Kamińska A., Gronowska-Senger A.: Ocena poziomu wiedzy żywieniowej u osób z zaburzeniami odżywiania [The assessment of nutritional knowledge of persons with eating disorders]. Rocz Państ Zakł Hig 2007; 58(1): 191-196 (in Polish).

6. Davis C., Carter JC.: Compulsive overeating as an addiction disorder. A review of theory and evidence. Appetite 2009; 53(1): 1-8.

7. Dutkiewicz A., Grzelak T.: Dietoterapia doustna u pacjentów z anoreksją [Diet therapy in patients with anorexia]. Psychiatr Psychol Klin 2016; 16(2): 104-109 (in Polish).

8. Gustek S., Jaworski M.: Znaczenie interwencji żywieniowej w psychoterapii poznawczo-behawioralnej $\mathrm{w}$ bulimii [The importance of nutrition intervention in cognitive-behavioral therapy (CBT) in bulimia]. Psychiatria i Psychoterapia 2011; 7(2/3): 7-21 (in Polish).

9. Hay P., Chinn D., Forbes D., Madden S., NewtonR., Sugenor L., Touyz S., Ward W., Royal Australian and New Zealand College of Psychiatrists.: Royal Australian and New Zealand College of Psychiatrists clinical practice guidelines for the treatment of eating disorders. Aust N Z J Psychiatry 2014; 48(11): 1-62.

10. Hsu L.K., Rand W., Sullivan S.: Cognitive therapy, nutritional therapy and their combination in the treatment of bulimia nervosa. Psychol Med 2001; 31(5): 871-879.

11. Instytut Żywności i Żywienia. Wskaźnik Queteleta. Available at: http://www.izz.waw.pl/pl/component/ licznikbmi/?Itemid=32 (Accessed 16 February 2018). 
12. Janas-Kozik M., Zejda J., Stochel M., Brożek G., Janas A., Jelonek I.: Ortoreksja - nowe rozpoznanie? [Orthorexia - a new diagnosis?]. Psychiatr Pol 2012; 46(3): 441-450 (in Polish).

13. Kowalik A., Wronka L., Sińska B.: Diabulimia niespecyficzne zaburzenia odżywiania w cukrzycy typu 1. [Diabulimia - non-specific eating disorders in type 1 diabetes]. Żyw Człow 2012; 39(1): 29-37 (in Polish).

14. Kręgielska-Narożna M., Walczak-Gatęzewska M., Lis I., Bogadański P.: Jadłowstręt psychiczny - co widzą „motyle”? [Anorexia nervosa - what ,butterflies” see?]. Farmacja Współcz 2014; 7: 1-6 (in Polish).

15. Laessle R.G., Beumont P.J., Butow P. Lennerts W. O'Connor M., Pirke K.M., Touyz S.W., Waadt S... A comparison of nutritional management with stress management in the treatment of bulimia nervosa. Br J Psychiatry 1991; 159: 250-261.

16. Laessle R., Schweiger U., Daute-Herold U. Schweiger M., Fichter M., Pirke K.: Nutritional knowledge in patients with eating disorders. Int J Eat Disord 1998; 7(1): 63-73.

17. Michalska A., Szejko N., Jakubczyk A., Wojnar M.: Niespecyficzne zaburzenia odżywiania się subiektywny przegląd [Nonspecific eating disorders a subjective review]. Psychiatr Pol 2016; 50(3): 497507 (in Polish).

18. National Eating Disorder Association. What are eating disorders? Available at: https://www.nationaleatingdisorders.org/what-are-eating-disorders (Accessed 15 February 2018).
19. O'Connor M., Touyz S., Beumont P.: Nutritional management and dietary counseling in bulimia nervosa: Some preliminary observations. Int J Eat Disord 1998; 7: 657-662.

20. Ostachowska-Gasior A., Krzeszowska-Rosiek T., Górska S.: Ocena wiedzy żywieniowej osób o wysokiej aktywności fizycznej uczęszczających do klubów fitness [Evaluation of nutritional knowledge among fit individuals attending fitness clubs]. Probl Hig Epidemiol 2014; 95(4): 969-974 (in Polish).

21. Salwach-Kuberska D., Majkowicz M., EysiakSzydłowska $W$.: Nawyki żywieniowe oraz aktywność fizyczna pacjentek $\mathrm{z}$ jadłowstrętem psychicznym [Eating habits and physical activity of patients with anorexia nervosa]. Post Żyw Klin 2014; 10(3): 5-10 (in Polish).

22. Serfaty M., Turkington D., Heap $M$ et al.: Cognitive therapy versus dietary counselling in the outpatient treatment of anorexia nervosa: effects of the treatment phase. Eur Eat Disord Rev 1999; 7: 334-350.

23. Waisberg J.L., Woods M.T.: A nutrition and behaviour change group for patients with anorexia nervosa. Can J Diet Pract Res 2002; 63(4): 202-205.

24. Weker H., Barańska M., Riahi A.: Problem otyłości a wiedza żywieniowa u młodzieży w wieku 13-15 lat [Nutritional education of obese adolescents aged 13-15 years]. Rocz Panstw Zakl Hig 2007; 58(1): 321-326.

Received: 11.08 .2018

Accepted: 12.12 .2018

This article is available in Open Access model and licensed under a Creative Commons Attribution-Non Commercial 3.0.Poland License (CC-BY-NC) available at: http://creativecommons.org/licenses/by-nc/3.0/pl/deed.en 